\title{
Molecular Docking Simulation Studies of Curcumin and Its Derivatives as Cyclin-Dependent Kinase 2 Inhibitors
}

\author{
Siklin Bağımlı Kinaz 2 İnhibitörü Olarak Kurkumin ve Türevlerinin \\ Moleküler Kenetlenme Simülasyonları
}

\author{
(D) Riyadi SUMIRTANURDIN*, (D) Shafira SUNGKAR, (D) Yasarah HISPRASTIN, (D) Kenny Dwi SIDHARTA, (D) Dea Dian NURHIKMAH \\ Universitas Padjadjaran, Faculty of Pharmacy, Department of Medicinal Chemistry, Bandung, Indonesia
}

\begin{abstract}
Objectives: Cyclin-dependent kinase 2 (CDK2) is a protein that plays a role in regulating the cell cycle and its overexpression contributes to uncontrolled cell proliferation. Inhibition of CDK2 is known to be a mechanism of action of various anti-cancer drugs. Curcumin is an active compound of Curcuma longa and it has been reported to inhibit the activity of cyclin D, cyclin E, CDK2, CDK4, and CDK6. This study aimed to design more active curcumin derivatives as anticancer drugs by targeting CDK2 through a molecular modeling approach.

Materials and Methods: The molecular modeling approach consists of receptor and ligand preparation, method validation, pharmacophore modeling, and docking simulation.

Results: The results of the molecular docking simulation show that the free bonding energy $(\Delta G)$ of curcumin and kurkumod 23 and 24 (the best modification of curcumin) are $-7.80,-9.15$, and $-9.36 \mathrm{kcal} / \mathrm{mol}$, respectively. The hydrogen interaction between kurkumod 23 and 24 with CDK occurred on Lys33 residue, which is considered a potential interaction site for CDK2 inhibitor compounds. Pharmacophore modeling showed that kurkumod 23 and 24 have pharmacophore-fit values of $45.20 \%$ and $47.26 \%$, respectively.

Conclusion: The results of this study indicate that kurkumod 23 and 24 are the best and most potent modifications of curcumin as CDK2 antagonist, based on the interactions that occur between these two derivatives with amino acid residues from the CDK2 receptor.
\end{abstract}

Key words: CDK2, curcumin, molecular docking, pharmacophore modeling

Öz

Amaç: Siklin bağımlı kinaz 2 (CDK2) hücre siklusunun regülasyonunda rol alan bir proteindir ve yüksek derecede ekspresyonu kontrol edilemeyen hücre proliferasyonuna yardımcı olur. CDK2'nin inhibisyonu birçok anti-kanser ilacının etki mekanizmasıdır. Kurkumin Curcuma longa'nın aktif bileşenidir ve siklin D, siklin E, CDK4 ve CDK6'yı inhibe ettiği rapor edilmiş̦tir. Bu çalışmanın amacı bir moleküler modelleme yaklaşımı ile CDK2'yi hedefleyerek daha aktif kurkumin türevlerinin tasarlanmasıdır.

Gereç ve Yöntemler: Moleküler modelleme yaklaşımı bir reseptör ve ligand hazırlanması, yöntem validasyonu, farmakofor modellemesi ve kenetleme simülasyonu içermektedir.

Bulgular: Moleküler kenetleme simülasyonunun sonucu kurkumin, kurkumod 23 ve $24^{\prime}$ ün serbest bağlanma enerjilerinin ( $\Delta G$ ) sırasılyla $-7,80,-9,15$ ve $-9,36 \mathrm{kcal} / \mathrm{mol}$ olduğunu göstermiștir. Kurkumod 23 ve 24'ün CDK ile hidrojen etkileșimi Lys33 kalıntısı üzerinde olmaktadır ki bu CDK2'yi inhibe eden bileșiklerin potansiyel etkileșim bölgesi kabul edilmektedir. Farmakofor modelleme, kurkumod 23 ve 24 'ün farmakofor-uyma değerlerini sırasıyla \%45,20 ve \%47,26 olarak göstermiştir.

Sonuç: Bu çalışmanın sonuçları CDK2 reseptöründeki amino asit kalıntılarıyla bu iki türevin etkileşimine dayanarak kurkumod 23 ve 24 'ün kurkuminin CDK2 antagonisti olan en iyi ve en potent modifikasyonları olduğunu işaret etmektedir.

Anahtar kelimeler: CDK2, kurkumin, moleküler kenetlenme, farmakofor modelleme

*Correspondence: E-mail: riyadidarn@gmail.com, Phone: +088222666852 ORCID-ID: orcid.org/0000-0002-5826-2703

Received: 20.01.2019, Accepted: 28.03.2019

-Turk J Pharm Sci, Published by Galenos Publishing House. 


\section{INTRODUCTION}

Cancer is a condition of uncontrolled cell growth that can affect the growth of cells and/or other tissues around them through the circulatory system and lymphatic system. Generally, various types of cancer occur due to the overexpression of proteins that play a role in the cell cycle, i.e. cyclin dependent kinase 2 (CDK2). The cell cycle is controlled by several proteins that act as positive and negative regulators. In mammals' cyclin protein groups, especially cyclin D, E, A, and B, expression fluctuates during the cell cycle process. Cyclin proteins together with the protein kinase (CDK) group, specifically CDK 4, 6, and 2, act as positive regulators that spur the occurrence of cell cycles. If a positive regulator experiences overexpression it can trigger acceleration of the cell cycle, thus triggering cell proliferation making the cell cycle difficult to control.' Furthermore, cancer is known to be one of the biggest causes of death in most developing countries (https://www.cancer.gov/about-cancer/ understanding/what-is-cancer). Therefore, research on new therapeutic agents for cancer treatment has always been a critical issue. The aim is to immediately address excessive cell proliferation and immediately prevent the metastatic process. At present, the molecular modeling approach, driven by the rapid development of computational chemistry, plays an important role in drug design and the discovery of new mechanisms from structure-based medicine. This method has been successfully used in many studies to discover new drugs. ${ }^{2}$

Some natural compounds are known to have the potential to become lead compounds in terms of inhibiting the growth of cancer cells, one of which is curcumin. Curcumin is a hydrophobic polyphenol obtained from turmeric rhizome (Curcuma longa L.) and is considered an active anticancer substance. ${ }^{3-5}$ Both preclinical and clinical studies have been carried out to learn the anticancer effects of curcumin compounds, including its role in proliferation arrest of MCF7 breast cancer cells, which is associated with their ability to inhibit cyclin D, cyclin E, CDK2, CDK4, and CDK6 activities and its ability to induce apoptosis through the caspase-9 mechanism. ${ }^{6}$ Therefore, the study of curcumin activity and the search for their active derivatives as new anticancer agents targeting CDK2 protein through the molecular modeling approach is thought to be one of the best ways to provide new cancer treatments alternative to the one that is currently available.

\section{MATERIALS AND METHODS}

\section{Materials}

The hardware used in the present study was a personal computer with the following specifications: Intel ${ }^{\circledR}$ Core $^{\mathrm{TM}}$ i56600 CPUa3.90 GHz (4CPUs), Nvidia Geforce GTX 970 GPU 4 Gigabyte OC Edition, and 8 Gigabyte DDR4 RAM. The in silico testing used the following software:

1. ChemOffice 2010 and ChemDraw Ultra 12.0 to create 2D structures and convert them to 3D structures.

2. LigandScout 4.0 (Wolber and Inte: Ligand $\mathrm{GmbH}$ ) to conduct pharmacophore modeling.
3. AutoDock 4.2.6 and AutoDockTools 1.5.6 (The Scripps Research Institute, downloaded from http://www.autodock. scripps.edu/) to conduct molecular docking simulation.

4. BIOVIA Discovery Studio 2017 for visualizing Protein Data Bank (PDB) complexes, bonds between ligands and cyclic dependent kinase 2, geometry optimization, and overlaying on the validation process.

The three-dimensional structure of the CDK2 protein was downloaded from the PDB (GDP) (http://www.rscb.org/) (ID: 1KE6) as well as the three-dimensional structure of curcumin and its derivatives' structure, which was illustrated using ChemOffice 2010 software.

\section{Receptor and ligand preparation}

The CDK2 structure used was downloaded from the PDB website. It was then separated from the ligands and water molecules and added with charges. The standard ligand was obtained from the results of the separation process, while the curcumin and its derivatives were designed by software and then optimized. The curcumin's derivatives' design is based on Lipinski's rule of five (RO5).

\section{Method validation}

Validation of the computational methods including validation of the molecular docking process was based on the root mean square deviation (RMSD) values of the standard ligand redocking process, while validation of the pharmacophore modeling process was based on the area under curve $100 \%$ (AUC100\%) value of the receiver operating characteristic (ROC) curve, which screened 778 active compounds and 2015 inactive compounds obtained from Directory of Useful Decoys, Enhanced (DUDe) from https://dude.docking.org.

\section{Pharmacophore modeling}

This process was carried out to see the level of similarity between curcumin and its modification with standard ligands where virtual screening was done using a validated structurebased 3D pharmacophore model and utilizing software assistance. The level of similarity of each structure was shown through the value of pharmacophore fit.

\section{Docking simulation}

Docking was simulated at the center of the active side of the receptor with the grid coordinates $x=27.440, y=10.959, z=11.192$ and the dimensions were $40 \times 40 \times 40$ points. The docking parameters were based on the Lamarckian genetic algorithm with 10 runs, 150 population size, 250,000 evaluation energy, gene mutation rate of 0.02 , and crossover rate of 0.8 . The conformation of the results of molecular docking simulation was clustered using RMSD $1.0 \AA$ A tolerance. Ligand conformation with the lowest free bond energy $(\Delta G)$ of the best cluster was used for the next analysis phase. The ligand-receptor complex formed was visualized with the help of software. 


\section{RESULTS AND DISCUSSION}

\section{CDK2 receptor preparations}

CDK2, downloaded from the PDB website with the code ID GDP 1KE6, was used. The CDK2 receptor was complexed with the antagonist ligand N-methyl-\{4-[2-(7-oxo-6,7-dihydro8h-[1,3] thiazolo [5,4-e]indol-8-ylidene)hydrazino]phenyl\} methanesulfonamide, which was obtained from $X$-ray diffraction with a resolution of $2.0 \AA$. Resolution describes the detailed structure of a complex and it illustrates the interaction between the ligand and active site. ${ }^{7}$ A smaller value of resolution will give more accurate results of constituent atom mapping. The ligand receptor complex was separated with the assistance of BIOVIA Discovery Studio software. The water molecules around the structure of receptors resulting from separation were then removed again with the aim of simplifying the docking process later. At the receptor, Kollman charges were added to suit the docking environment and hydrogen was added to polar atoms.

\section{Ligand preparation}

The ligand that was determined as the standard was obtained through a separation process with CDK2 receptors with the help of software. Furthermore, the test ligands, namely curcumin and its derivatives (kurkumod), were designed and optimized with the software described above. Table 1 shows the structure and properties of each proposed curcumin derivative. The curcumin derivative design is based on keeping the original pharmacophore that was found in the curcumin compound. Optimization of the ligand includes energy minimization and the addition of the Gasteiger charge and then the hydrogen atom in the polar site of the molecule. The design of the curcumin modification is also based on Lipinski's R05, which predicts the ability of a compound to penetrate the membrane if given orally. This rule includes a molecular weight of $\leq 500 \mathrm{Da}$, hydrogen bond donors $\leq 5$, hydrogen bond acceptors $\leq 10$, LogP value $\leq 5$, and molar reactivity in the range between 40 and $130 .{ }^{8}$

\section{Method validation results}

Validation of computational methods is performed to prove and ensure that the method used meets the validity requirements and can be used for testing other molecules and thus minimizing errors.

\section{Validation of the docking simulation method}

The docking simulation process was validated by using AutoDock 4.1 and AutoDockTools software through the redocking procedure of ligands that have been previously separated from the receptor. Redocking results are said to be valid if in 10 numbers of a run a minimum of $75 \%$ RMSD value $\leq 2 \AA$. RMSD is the ratio between the distance change and the best ligand conformation from the simulation results with distance and initial ligand conformation.

The results of ligand redocking to CDK 2 receptors produced free energy $(\Delta G)$ of $-10.53 \mathrm{kcal} / \mathrm{mol}$ with an RMSD value of 0.85 $\AA$ and all of 10 runs resulted in an RMSD value $\leq 2 \AA$, as depicted in Figure 1. The redocking results also show that ligands form hydrogen bonds with Leu83, Asp86, and Asp145, in accordance
Table 1. Standard ligand, curcumin, kurkumod structure, and its

physicochemical properties

Molecule Structure

name

Physicochemical properties

\begin{tabular}{|c|c|c|}
\hline 1. & $\begin{array}{l}\text { Standard } \\
\text { ligand } \\
(1 \text { ke6) }\end{array}$ & $\begin{array}{l}M W=401.467 \\
\operatorname{LogP}=2.349 \\
N H D=3 \\
N H A=5\end{array}$ \\
\hline 2. & Curcumin & $\begin{array}{l}M W=368.385 \\
\operatorname{LogP}=3.62 \\
N H D=2 \\
N H A=6\end{array}$ \\
\hline 2. & $\begin{array}{l}\text { Kurkumod } \\
11\end{array}$ & $\begin{array}{l}M W=353.547 \\
\operatorname{LogP}=2.763 \\
N H D=4 \\
N H A=3\end{array}$ \\
\hline 3. & $\begin{array}{l}\text { Kurkumod } \\
17\end{array}$ & $\begin{array}{l}M W=289.375 \\
\operatorname{LogP}=1.994 \\
N H D=3 \\
N H A=0\end{array}$ \\
\hline 4. & $\begin{array}{l}\text { Kurkumod } \\
18\end{array}$ & $\begin{array}{l}M W=369.484 \\
\operatorname{LogP}=-2.214 \\
N H D=2 \\
N H A=1\end{array}$ \\
\hline 5. & $\begin{array}{l}\text { Kurkumod } \\
19\end{array}$ & $\begin{array}{l}M W=348.445 \\
\operatorname{LogP}=0.418 \\
N H D=1 \\
N H A=1\end{array}$ \\
\hline 6. & $\begin{array}{l}\text { Kurkumod } \\
20\end{array}$ & $\begin{array}{l}M W=360.456 \\
\operatorname{LogP}=0.898 \\
N H D=0 \\
N H A=2\end{array}$ \\
\hline 7. & $\begin{array}{l}\text { Kurkumod } \\
21\end{array}$ & $\begin{array}{l}M W=348.445 \\
\operatorname{LogP}=0.680 \\
N H D=2 \\
N H A=1\end{array}$ \\
\hline 8. & $\begin{array}{l}\text { Kurkumod } \\
23\end{array}$ & $\begin{array}{l}M W=348.445 \\
\operatorname{LogP}=0.680 \\
N H D=1 \\
N H A=2\end{array}$ \\
\hline 9. & $\begin{array}{l}\text { Kurkumod } \\
24\end{array}$ & $\begin{array}{l}M W=348.445 \\
\operatorname{LogP}=0.740 \\
N H D=1 \\
N H A=2\end{array}$ \\
\hline
\end{tabular}

MW: Molecular weight, NHD: Number of hydrogen bond donor, NHA: Number of hydrogen bond acceptors 


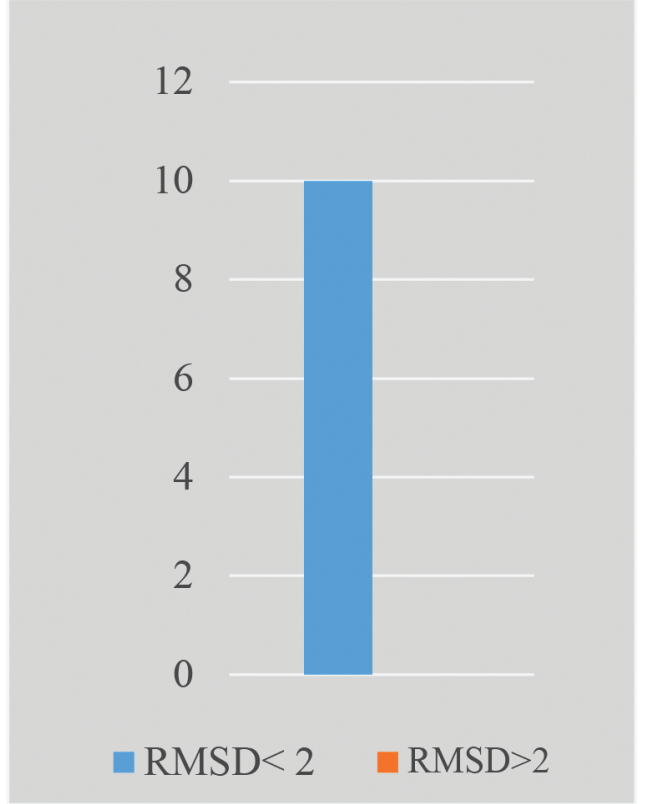

Figure 1. Redocking result of 10 runs of standard ligand to CDK2 receptor CDK2: Cyclin-dependent kinase 2, RMSD: Root mean square deviation

with the ligand initial bond conditions with the receptors. Figure 2 exhibits superimposition between native and redocked ligand and CDK2 receptor. The validation parameters were fulfilled and so the computational method used is said to be valid and can be used for further testing.

\section{Pharmacophore modeling validation result}

This validation aims to see the accuracy of the program in detecting active sets and decoy sets. Validation was carried out through screening 778 active compounds and 2015 inactive compounds obtained from DUDe (https://dude.docking.org). The active set is a set of compounds or ligands that are known to be active at certain receptors with known IC50 values from the results of previous studies. Decoy sets are sets of ligands that have a structure similar to that of active sets but are not active against receptors. The screening results show an enrichment factor $100 \%$ (EF100\%) and AUC100\% of 1.825 and 0.67 , respectively, on the ROC curve. The greater the AUC value, the better the classification will be. The best results from virtual screening are indicated by the maximum AUC value, i.e. the value equals $1 .{ }^{9}$ The ROC curve is the most common quality validation parameter used for pharmacophore modeling, where this curve consists of the $X$ axis as the rate of inactive compounds on the pharmacophore model and the $Y$ axis as the rate of the active compound on the pharmacophore model.

\section{Pharmacophore modeling result}

The results of the pharmacophore modeling will show the level of similarity between the modification of curcumin (kurkumod) and the standard CDK2 ligand (protein 1KE6 ligand). Values of pharmacophore similarity between these two compounds will be shown as pharmacophore-fit values. The test results show that the best modified compounds, namely kurkumod 23 and 24 , each have a similarity level of $45.2 \%$ and $47.26 \%$ to CDK2 standard ligands, as described in Table 2.

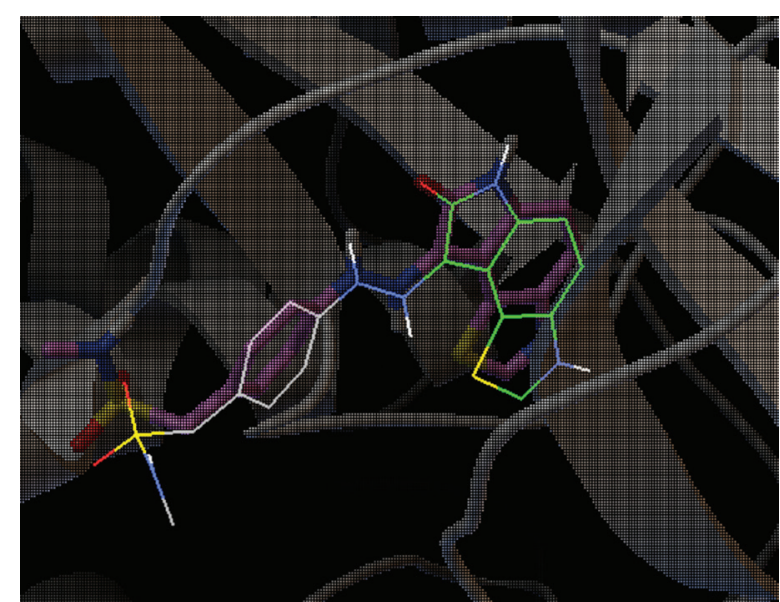

Figure 2. Superimposition illustration of native ligand and redocked ligand to CDK2 receptor (Native ligand shown green with thin line and redocked ligand shown purple with thick line)

CDK2: Cyclin-dependent kinase 2

\section{Docking simulation results}

The molecular docking method aims to see the interaction between ligands, i.e. curcumin and its derivatives with the target receptor, CDK2. The results of this process were the Gibbs free energy $\Delta G$, inhibition constant, number of clusters, and types of bonds to amino acid residues. The results of the curcumin docking and its derivative along with the standard CDK2 ligand against the CDK2 receptor itself can be seen in Table 3. Based on the results, modification of kurkumod 23 and 24 shows that the value of $\Delta G$ tends to be lower than the modification of kurkumod 11, 17, and 20 although it has not been able to compensate for the free energy values of standard CDK2 ligands ( $\Delta G-10.53$ ) and modification 18,21 , and 19. Lower bond energy indicates that the interaction that occurs has a higher affinity because it tends to be easier (less energy) to interact. The cluster number of derivatives kurkumod 23 and 24 is also at the level where the first ranking cluster has more members than other clusters. More cluster numbers indicate that the poses of the conformation produced are more stable.

The consideration that kurkumod 23 and 24 are the best modifications of curcumin is based on the interactions that occur between these two derivatives with amino acid residues from the CDK2 receptor, as illustrated in Figure 3. Activation of CDK2 through complexation with cyclin A will induce conformational changes on the ATP binding site. The most significant effect is the rotation of helix $\mathrm{C}$, which causes changes in the geometry of the active site in the area of three active site catalyst residues, namely Lys33, Glu51, and Asp145. The Lys33 amino acid residue is considered a potential interaction site for inhibitor compounds. The carboxylic acid molecule, which has been reported as an active CDK2 inhibitor, is known to form hydrogen bonds with Lys-33 on CDK2 receptor residues. Therefore, kurkumod 23 and 24 , which both form hydrogen interactions with Lys33, are considered potential CDK2 inhibitors. ${ }^{10}$

On the other hand, kurkumod 23 also shows hydrogen bonds with amino acid residues Glu81 and Leu83 on CDK2. The NH 
hydrogen amide bond with Glu81 and the hydrogen bond from the oxygen carbonyl group with Leu83 are analogous interactions that occur between ATP and CDK2. Hydrophobic interactions also occur between benzene rings from kurkumod 23 and 24 with the hydrophobic environment of CDK2 receptors (Val18 and Leu134). ${ }^{10}$

\section{Table 2. Pharmacophore-fit score of curcumin derivatives against} CDK2

Name of

Pharmacophore-fit

Pharmacophore model

derivatives

value
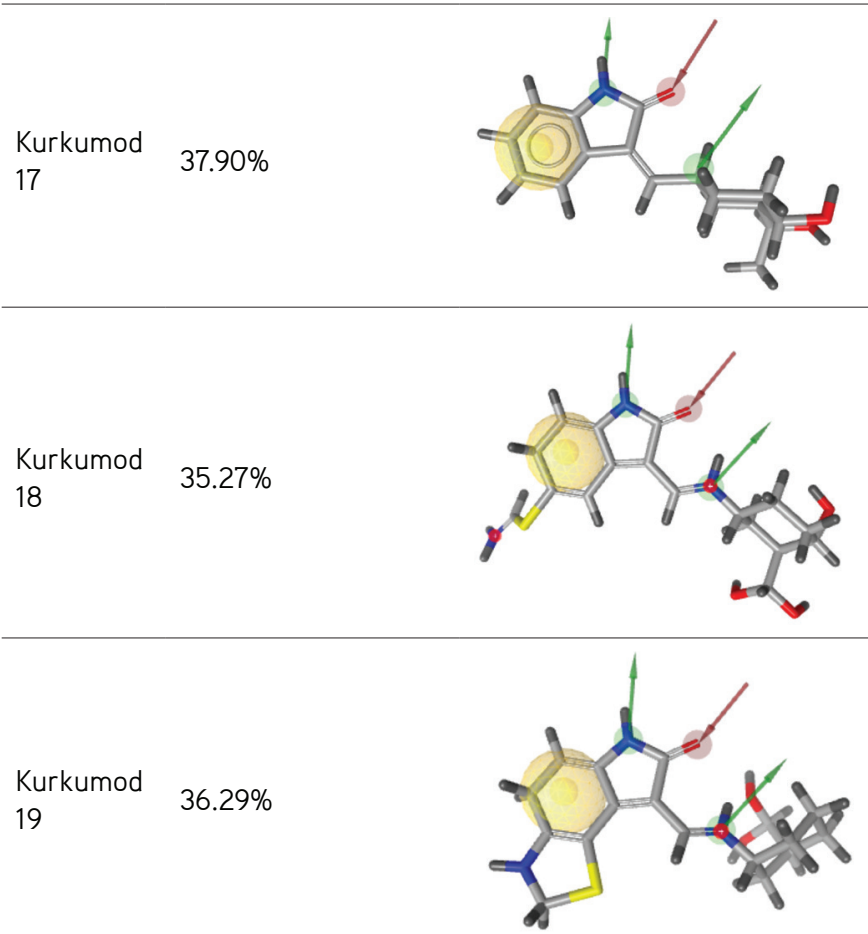
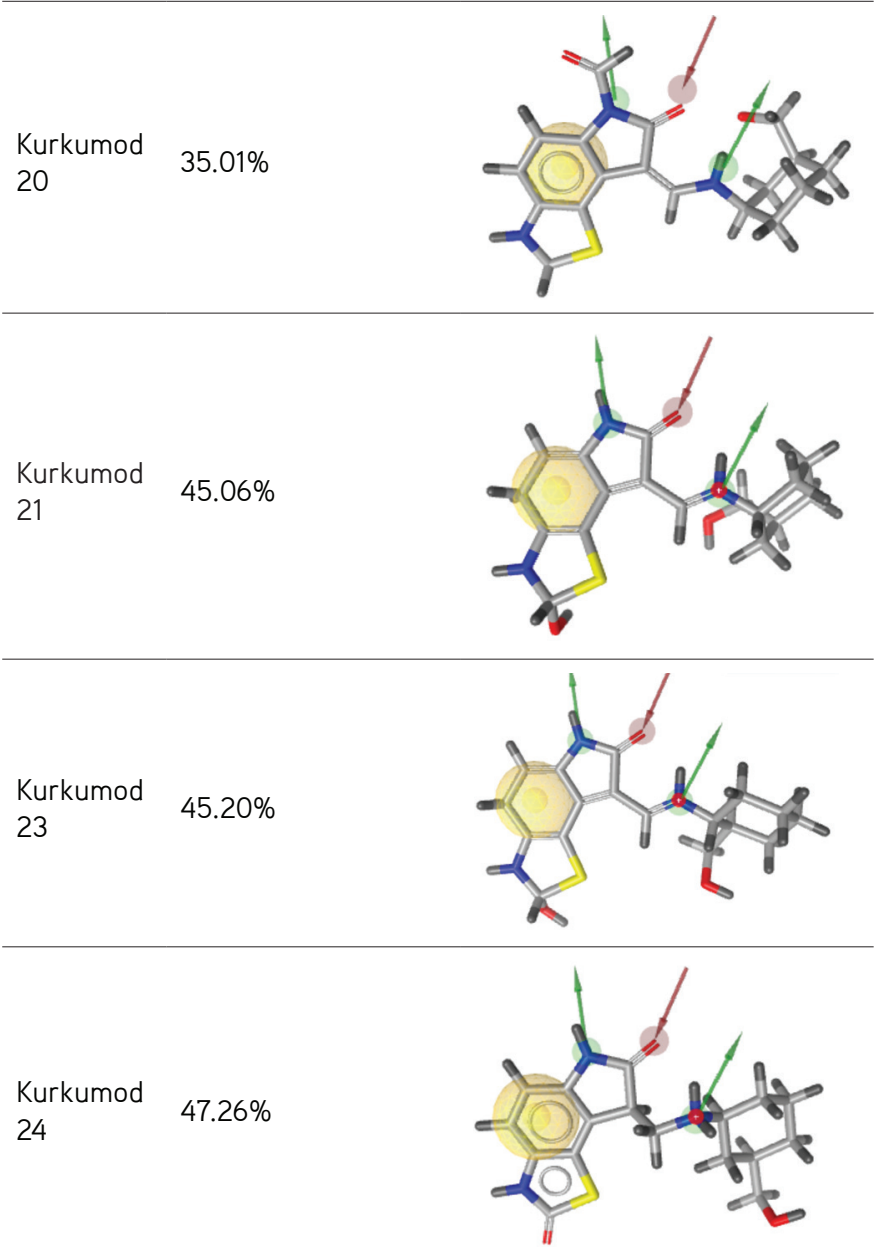

CDK2: Cyclin-dependent kinase 2

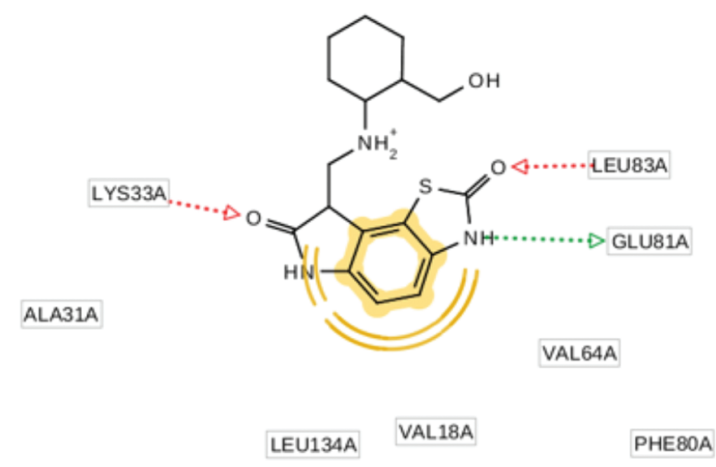

Kurkumod 23

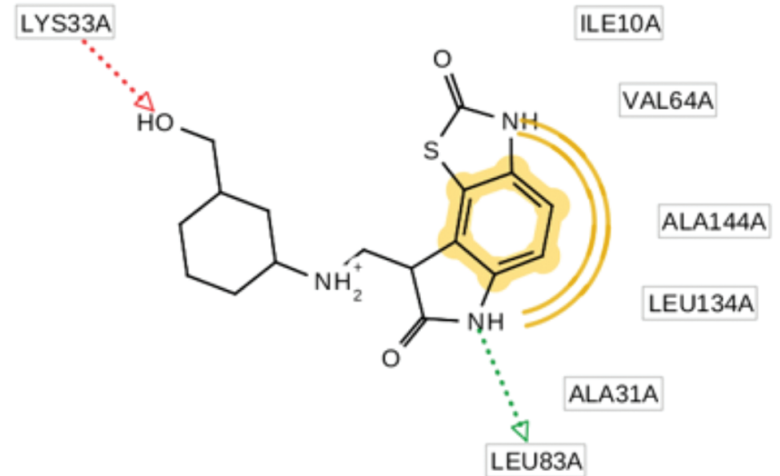

Kurkumod 24

Interactions

(Red arrow): Hydrogen bond (acceptor)

(Green arrow): Hydrogen bond (donor)

(Yellow sphere): Van der Waals interaction

Figure 3. Interaction of kurkumod 23 and 24 with CDK2 active site CDK2: Cyclin-dependent kinase 2 
Table 3. Ligand interaction with CDK2 active site

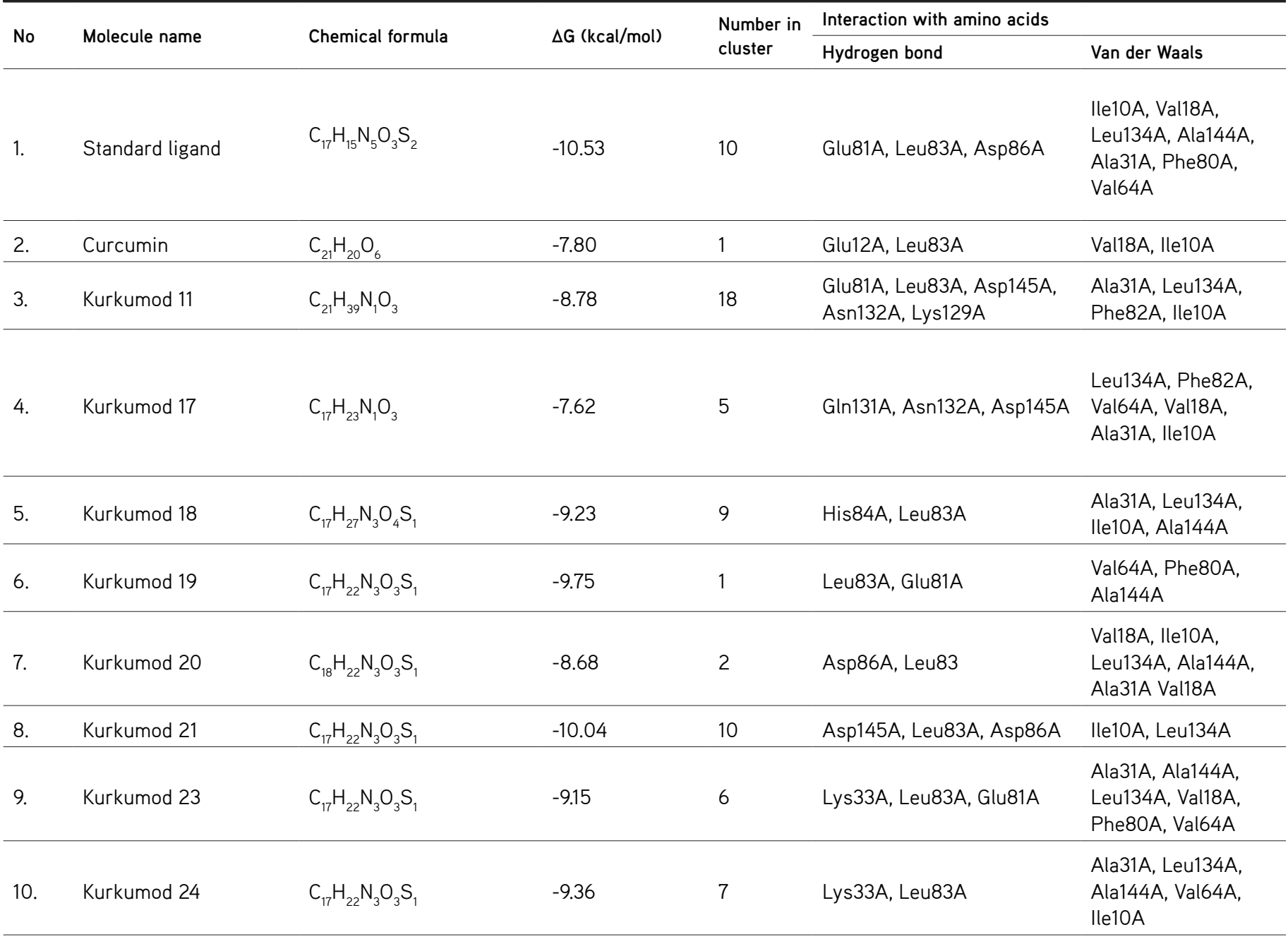

CDK2: Cyclin-dependent kinase 2

\section{Study Limitation}

This was a preliminary study related to the design of derivatives of natural compounds that have potential as anticancer agents. The synthesis of the proposed compound and then in silico in vitro correlation analysis are expected in the future.

\section{CONCLUSION}

Kurkumod 23 and 24 are the best and most potent modifications of curcumin as CDK2 antagonist, based on the interactions that occur between these two derivatives with amino acid residues from the CDK2 receptor.

\section{ACKNOWLEDGEMENTS}

The authors would like to thank our team: Hisban Hamid Arifki, Yunistya Dwi Cahyani, Alfia Nursetiani, Traju Ningtyas Dwi Utari, and Jessica Tristi for the great team collaboration.

Conflicts of interest: No conflict of interest was declared by the authors. The authors alone are responsible for the content and writing of the paper.

\section{REFERENCES}

1. Hamzah N, Najib A, Fatmawati S. Studi Farmakofor Reseptor Estrogen $\alpha$ sebagai Target Terapi Kanker Serviks. Jurnal Farmasi FIK UIN Alauddin. 2014;2:133-137.

2. de Ruyck J, Brysbaert G, Blossey R, Lensink MF. Molecular docking as a popular tool in drug design, an in silico travel. Adv Appl Bioinform Chem. 2016;9:1-11.

3. Grynkiewicz G, Ślifirski P. Curcumin and curcuminoids in quest for medicinal status. Acta Biochim Pol. 2012;59:201-212.

4. Borik RM, Fawzy NM, Abu-Bakr SM, Aly MS. Design, Synthesis, Anticancer Evaluation and Docking Studies of Novel Heterocyclic Derivatives Obtained via Reactions Involving Curcumin. Molecules. 2018;23:1398.

5. Mutiah R. Evidence Based Kurkumin dari Tanaman Kunyit (Curcuma longa) sebagai Terapi Kanker pada Pengobatan Modern. Jurnal Farma Sains. 2015;1:28-41.

6. Li HQ, Jin JL, Wu FF, Li XY, You JS,Cao ZH, Li D, Xu YP. Effect of Curcumin on Proliferation, Cell cycle and caspase and MCF-7 cells. Afr J Med Med Sci. 2012;6:864-870.

7. Lipinski CA. Lead-and drug-like compounds: the rule-of-five revolution. Drug Discov Today Technol. 2004;1:337-341. 
8. Kang FN, Simoben CV, KAraman B, Ngwa VF, Judson PN, Sippl W, Mbaze LM. Pharmacophore modeling and in silico toxicity assessment of potential anticancer agents from african medicinal plants. Drug Des Devel Ther. 2016;10:2137-2154.

9. Vakser IA. Protein-protein docking: from interaction to interactome. Biophys J. 2014;107:1785-1793.
10. Bramson HN, Corona J, Davis ST, Dickerson SH, Edelstein M, Frye SV, Gampe Jr RT, Harris P A, Hassell A, Holmes WD, Hunter RN, Lackey KE, Lovejoy B, Luzzio MJ, Montana V, Rocque, D Rusnak WJ, Shewchuk L, Veal JM, Walker DH, Kuyper LF. Oxindole-based inhibitors of cyclindependent kinase 2 (CDK2): design, synthesis, enzymatic activities, and X-ray crystallographic analysis. J Med Chem. 2001;44:4339-4358. 